\title{
Long-term survival of patients with incomplete bundle-branch block complicating acute myocardial infarction ${ }^{1}$
}

\author{
Edgar Lichstein, Prem K. Gupta, and Kul D. Chadda \\ From the Department of Medicine, Division of Cardiology, Mount Sinai Hospital Services, City Hospital \\ Center at Elmhurst, Mount Sinai School of Medicine of the City University of New York, U.S.A.
}

Electrocardiograms and His bundle electrograms were reviewed in 28 patients with incomplete bilateral bundle-branch block complicating acute myocardial infarction.

All had a His bundle electrogram at the time of pacemaker insertion; to had a second one. Of 23 patients with an initially abnormal HV interval ( 55 ms or greater), 15 died (65\%), while only one died (20\%) in the group of 5 with a normal HV interval. This difference is not statistically significant. Sequential His bundle electrograms were done in 6 of the 8 survivors with an initially abnormal HV interval, and 4 showed Io to I5 ms decrease in HV interval. The disappearance of incomplete bilateral bundle-branch block occurred significantly more often in patients who survived (7 of I2) when compared with those who did not survive ( 2 of I6) $(P<0.05)$.

It is concluded that long-term survival is possible after incomplete bilateral bundle-branch block complicating acute myocardial infarction. The characteristics of the survivors include an initially normal $H V$ interval, transient incomplete belateral bundle-branch block and a decreasing $H V$ interval if it were initially abnormal.

Bundle-branch block complicating acute myocardial infarction is associated with an increased mortality (Godman, Lassers, and Julian, 1970; Atkins et al., 1973). This increased mortality is related to both a greater amount of myocardial damage and a greater risk of complete heart block and asystole (Fenig and Lichstein, 1972).

Various forms of incomplete bilateral bundlebranch block have been recognized as precursors of complete heart block (Scanlon, Pryor, and Blount, 1970). These include right bundle-branch block with left anterior hemiblock, right bundle-branch block with left posterior hemiblock, alternating right bundle-branch block and left bundle-branch block in the same or serial tracings, and first degree atrioventricular block with bundle-branch block and an unusually prolonged QRS. Though some reservations exist (Godman et al., 1970; Scheinman and Brenman, 1972), immediate insertion of a

Received 3 February 1975.

${ }^{1}$ Portions of this study were presented at the $47^{\text {th }}$ Session of the American Heart Association in Dallas, Texas, November, I974. temporary prophylactic pacemaker when incomplete bundle-branch block complicates acute myocardial infarction has been widely recommended (Atkins et al., 1973; Fenig and Lichstein, 1972; Roos and Dunning, 1970; Norris, 1969; Lassers and Julian, 1968). The mortality remains high despite this therapeutic intervention (Gould et al., 1972).

In addition to complete heart block occurring during the initial hospital admission, later recurrence of complete heart block in patients who had earlier transiently exhibited this has been reported. Atkins et al. (1973) recommend permanent pacemaker insertion in this group of patients and report improved survival when this is done. However, the role of permanent pacemaker insertion in patients with incomplete bundle-branch block complicating acute myocardial infarction but without transient complete heart block remains unknown.

In order to determine the role of permanent pacing in this latter group of patients, the natural history must first be established. This study describes the course of 28 patients with incomplete bundle-branch block complicating acute myocardial 
infarction. The mortality is examined with specific reference to the prognostic value of the His-Purkinje conduction time (HV interval) on admission, the change in HV interval with time, and the transient or persistent nature of the bundle-branch block.

\section{Subjects and methods}

There were 27 male patients and I female patient; the average age was 62 years (range 47 to 83 years). All patients were admitted to the coronary care unit at the City Hospital Center at Elmhurst between January I97I and May 1974. A standard 12-lead electrocardiogram was obtained on admission and then daily during their stay in the coronary care unit. In addition to constant oscilloscopic monitoring using a VI monitoring lead, frequent rhythm strips were obtained as well as complete repeat electrocardiograms whenever a change in rhythm or conduction was noted. A vectorcardiogram using the Frank lead system was obtained in most patients when a conduction defect was noted.

The criteria used for the diagnosis of acute myocardial infarction were the presence of abnormal $Q$ waves and serial ST-T wave changes in addition to characteristic serum creatinine phosphokinase, lactic acid dehydrogenase, and transaminase abnormalities. Right bundlebranch block was defined according to the criteria of the New York Heart Association (1964) and included a QRS duration of $0.12 \mathrm{~s}$ or more. Patients with right bundle-branch block and a $Q$ wave in lead VI were not listed separately. Diagnoses of left anterior and left posterior hemiblock were based on modifications of the criteria of Rosenbaum (1970). The criteria for left anterior hemiblock include a frontal plane QRS axis greater than $-30^{\circ}$ and for left posterior hemiblock a frontal plane $Q R S$ axis greater than $+100^{\circ}$. In patients with inferior wall infarction a diagnosis of left anterior hemiblock was made according to the vectorcardiographic criteria suggested by Benchimol, Desser, and Massey (1972) and for those with left posterior hemiblock a diagnosis was made according to the vectorcardiographic criteria established by Varriale and Kennedy (1972).

The conduction defects were all thought to be related to the acute myocardial infarction. Patients in whom previous electrocardiograms were not available and in whom time of onset of incomplete bundle-branch block could not be determined were excluded from the study.

A temporary prophylactic pacemaker was inserted as soon as one of the patterns of incomplete bundle-branch block was recognized. During insertion of the pacemaker a His bundle electrogram was obtained according to the method of Scherlag et al. (1969). The His bundle electrogram was recorded at a frequency range of 40 to $500 \mathrm{~Hz}$ at paper speeds of 100 and $150 \mathrm{~mm} / \mathrm{s}$. The electrode catheter was then positioned in the apex of the right ventricle. No significant ventricular irritability or other complications occurred during this procedure. In Io patients, a second His bundle electrogram was recorded at a later occasion; in 8 of these the second His bundle electrogram was recorded as the temporary pacemaker was being removed and this was usually 14 to 21 days after the onset of incomplete bundle-branch block. In 2 patients, the second recording was obtained on the third day after the onset of incomplete bundle-branch block, during repositioning of the pacemaker catheter.

An HV interval of $55 \mathrm{~ms}$ or greater was considered abnormal. In measuring sequential $\mathrm{HV}$ intervals a change of $5 \mathrm{~ms}$ or less was not considered to be significant. Statistical significance was determined by the $\chi^{2}$ method.

\section{Results}

Twenty-two patients had anterior wall myocardial infarction, 4 had inferior wall myocardial infarction, and 2 had evidence of both anterior and inferior wall myocardial infarction. Incomplete bilateral bundle-branch block was manifested as right bundle-branch block with left anterior hemiblock in 17, right bundle-branch block with left posterior hemiblock in 7 , and alternating right and left bundle-branch block in one. Three patients had right bundle-branch block, with periods of both left anterior hemiblock and left posterior hemiblock. In 21 patients, the incomplete bilateral bundle-branch block developed after hospital admission. In 2, it was present on admission and then disappeared and in 5 it was present on admission and persisted. In these latter 5, previous electrocardiograms were available and showed no evidence of incomplete bilateral bundle-branch block. The Table summarizes the clinical course of these patients.

Complete heart block occurred in 4 patients $(14 \%)$. None of these patients survived in spite of the use of a pacemaker. Case 3 died suddenly, presumably of ventricular fibrillation, 2 weeks after permanent pacemaker implantation. Case 19 died in cardiogenic shock, and Cases 20 and 27 had ventricular fibrillation.

Twelve patients $(43 \%)$ died within the first 2 I days of being admitted to hospital: 8 died of ventricular fibrillation, 2 of cardiogenic shock, $I$ in congestive heart failure, and I of respiratory arrest. There were 4 late deaths between 6 weeks and 4 months (total mortality: 57\%): Case 3 mentioned above was one of these; Case II died of progressive congestive heart failure and Case 17 had a cerebral vascular accident (there was no evidence of heart block prior to cerebral vascular accident); Case 9 was not monitored and died suddenly at 4 months while in another hospital for recurrent chest pain. It is not known whether the terminal event was ventricular fibrillation or complete heart block.

Necropsy was obtained in 2 patients. Case II, 
TABIE

\begin{tabular}{|c|c|c|c|c|c|c|c|c|c|c|}
\hline $\begin{array}{l}\text { Case } \\
\text { No. }\end{array}$ & $\begin{array}{l}\text { Age } \\
(y r)\end{array}$ & Sex & $\begin{array}{l}E C G \text { on } \\
\text { admission }\end{array}$ & Progression & $\begin{array}{l}H B E( \\
\text { Date }\end{array}$ & $\begin{array}{l}m s) \\
A H\end{array}$ & $H V$ & $R B B B$ & $\begin{array}{l}\text { Follow-up } \\
\text { period }\end{array}$ & Status \\
\hline I & 56 & $\mathbf{M}$ & $\begin{array}{l}\text { AWMI, } \\
\text { RBBB-LAH }\end{array}$ & & & IIO & 60 & +-+-+ & 2 wk & Died, VF \\
\hline 2 & 47 & $\mathbf{M}$ & AWMI & RBBB-LAH day 2 & $\begin{array}{r}18 / 5 \\
6 / 6\end{array}$ & $\begin{array}{r}70 \\
140\end{array}$ & $\begin{array}{l}55^{\star} \\
45\end{array}$ & -+- & $22 \mathrm{mth}$ & Alive, angina \\
\hline 3 & 65 & $\mathbf{M}$ & $\begin{array}{l}\text { IWMI, } \\
\text { ILBBB }\end{array}$ & $\begin{array}{c}\text { CHB, RBBB- } \\
\text { LPH day } 2\end{array}$ & & I10 & 100 & -+ & $6 \mathrm{wk}$ & $\begin{array}{l}\text { Died suddenly } \\
2 \text { wk after } \\
\text { permanent } \\
\text { pacemaker } \\
\text { implant. }\end{array}$ \\
\hline 4 & 73 & $\mathbf{M}$ & AWMI & RBBB-LAH $7 \mathrm{hr}$ & & 60 & 50 & -+ & $2 \mathrm{dy}$ & $\begin{array}{l}\text { Died, respiratory } \\
\text { arrest }\end{array}$ \\
\hline 5 & 70 & $\mathbf{M}$ & $\begin{array}{l}\text { AWMI, } \\
\text { RBBB-LAH }\end{array}$ & $I^{\circ} \mathrm{AV}, \mathrm{LBBB}$ day 2 & & 120 & 70 & +- & 3 wk & Died, CHF \\
\hline 6 & 69 & $\mathbf{M}$ & AWMI, & RBBB day 3 & $\begin{array}{c}9 / 5 \\
30 / 5\end{array}$ & $\begin{array}{r}90 \\
120\end{array}$ & 50 & -+- & $22 \mathrm{mth}$ & $\begin{array}{l}\text { Alive on dig. } \\
\text { and diuretics }\end{array}$ \\
\hline $\begin{array}{l}7 \\
8\end{array}$ & $\begin{array}{l}63 \\
57\end{array}$ & $\begin{array}{l}\mathbf{M} \\
\mathbf{M}\end{array}$ & $\begin{array}{l}\text { AWMI } \\
\text { AWMI, }\end{array}$ & RBBB-LAH I hr & & 90 & 85 & -+ & $12 \mathrm{dy}$ & Died, VF \\
\hline 9 & 73 & $\mathbf{M}$ & $\begin{array}{l}\text { RBBB-LAH } \\
\text { ST } \downarrow \text { VI-V6 }\end{array}$ & $\begin{array}{l}\text { AWMI } \\
\text { RBBB-LPH day } 6\end{array}$ & & $\begin{array}{l}120 \\
120\end{array}$ & $\begin{array}{l}55 \\
65\end{array}$ & $\stackrel{+}{-+}$ & $\begin{array}{l}12 \mathrm{hr} \\
4 \mathrm{mth}\end{array}$ & $\begin{array}{l}\text { Died, shock } \\
\text { Died suddenly, } \\
\text { not on monitor }\end{array}$ \\
\hline IO & 68 & $\mathbf{M}$ & $\begin{array}{l}\text { AWMI, } \\
\text { RBBB-LAH }\end{array}$ & & & Iro & 50 & - & $20 \mathrm{mth}$ & Alive \\
\hline II & 53 & $\mathbf{M}$ & $\begin{array}{l}\text { AWMI, } \\
\text { IWMI }\end{array}$ & $\begin{array}{l}\text { RBBB-LAH } 2 \mathrm{hr} \\
\text { RBBB-LPH day } 2\end{array}$ & & 90 & 70 & -+-+- & $6 \mathrm{wk}$ & Died, \\
\hline 12 & 49 & $\mathbf{M}$ & AWMI & $\begin{array}{l}\text { RBBB-LAH } 2 \mathrm{hr} \\
\text { RBBB-LPH day } 2\end{array}$ & & 120 & 60 & -+ & $3 \mathrm{dy}$ & Died, VF \\
\hline $\begin{array}{l}13 \\
14\end{array}$ & $\begin{array}{l}80 \\
51\end{array}$ & $\begin{array}{l}\mathbf{M} \\
\mathbf{M}\end{array}$ & $\begin{array}{l}\text { AWMI } \\
\text { AWMI }\end{array}$ & $\begin{array}{l}\text { RBBB-LAH } 2 \mathrm{hr} \\
\text { LAH } 2 \mathrm{hr}\end{array}$ & & 100 & 60 & -+ & $20 \mathrm{mth}$ & Alive \\
\hline & & $\mathbf{M}$ & AWMI, & RBBB-LAH $4 \mathrm{hr}$ & & 80 & $\begin{array}{l}45 \\
80\end{array}$ & -+- & I9 mth & Alive \\
\hline 15 & 55 & $2 \sqrt{1}$ & RBBB-LAH & & $\begin{array}{r}0 / 4 \\
16 / 4\end{array}$ & $\begin{array}{l}120 \\
125\end{array}$ & $65^{\star}$ & +- & $12 \mathrm{mth}$ & Alive \\
\hline 16 & 62 & $\mathbf{M}$ & LAH & $\begin{array}{l}\text { AWMI day I } \\
\text { RBBB-LAH day I }\end{array}$ & $\begin{array}{r}17 / 5 \\
1 / 6\end{array}$ & $\begin{array}{l}70 \\
70\end{array}$ & 60 & -+ & $12 \mathrm{mth}$ & Alive \\
\hline $\begin{array}{l}17 \\
18\end{array}$ & $\begin{array}{l}72 \\
69\end{array}$ & $\begin{array}{l}\mathbf{M} \\
\mathbf{M}\end{array}$ & $\begin{array}{l}\text { AWMI } \\
\text { OIWMI, } \\
\text { AWMI }\end{array}$ & $\begin{array}{l}\text { RBBB-LPH } 2 \mathrm{hr} \\
\text { RBBB-LPH } 2 \text { hr }\end{array}$ & & $\begin{array}{l}70 \\
70\end{array}$ & $\begin{array}{l}85 \\
70\end{array}$ & $\begin{array}{l}-+ \\
-+-\end{array}$ & $\begin{array}{l}3 \mathrm{mth} \\
2 \mathrm{wk}\end{array}$ & $\begin{array}{l}\text { Died, CVA } \\
\text { Died, VFt }\end{array}$ \\
\hline 19 & 60 & $\mathbf{M}$ & IWMI & $\begin{array}{l}\text { LBBB day I } \\
\text { RBBB day II } \\
\text { CHB day I2 }\end{array}$ & & 80 & 60 & -+ & 3 wk & Died, shock \\
\hline 20 & 58 & $\mathbf{F}$ & AWMI, LAH & $\begin{array}{l}\text { RBBB-LAH } 2 \mathrm{hr} \\
\text { CHB day } 2\end{array}$ & $\begin{array}{l}25 / 2 \\
28 / 2\end{array}$ & $\begin{array}{l}\text { AF } \\
100\end{array}$ & $\begin{array}{l}55 \\
60\end{array}$ & -+ & $17 \mathrm{dy}$ & Died, $\mathrm{VF}^{+}$ \\
\hline $2 I$ & 52 & $\mathbf{M}$ & $A W M I$ & RBBB-LAH 6 hr & $\begin{array}{r}1 / 2 \\
20 / 2\end{array}$ & $\begin{array}{r}85 \\
80\end{array}$ & 65 & -+- & $3 \mathrm{mth}$ & Alive \\
\hline 22 & 77 & $\mathbf{M}$ & $\begin{array}{l}\text { IWMI } \\
\text { RBBB-LAH }\end{array}$ & RBBB-LAH & & 100 & 70 & + & $2 \mathrm{mth}$ & Alive \\
\hline 23 & 50 & $\mathbf{M}$ & AWMI & RBBB-LPH day 2 & $\begin{array}{l}9 / 3 \\
2 / 4\end{array}$ & $\begin{array}{l}75 \\
90\end{array}$ & $\begin{array}{l}60 \\
55\end{array}$ & -+ & $2 \mathrm{mth}$ & Alive \\
\hline 24 & 65 & $M$ & $\begin{array}{l}\text { IWMI, } \\
\text { RBBB-LAH }\end{array}$ & $\begin{array}{l}\text { RBBB-LPH day I } \\
\text { AWMI }\end{array}$ & $\begin{array}{r}9 / 3 \\
21 / 3\end{array}$ & $\begin{array}{r}80 \\
100\end{array}$ & $\begin{array}{l}80 \\
80\end{array}$ & + & $2 d y$ & Died, VF \\
\hline 25 & 54 & $\mathbf{M}$ & $\begin{array}{l}\text { AWMI, } \\
\text { IWMI }\end{array}$ & RBBB-LPH day 2 & $\begin{array}{r}9 / 5 \\
29 / 5\end{array}$ & $\begin{array}{l}\text { II5 } \\
110\end{array}$ & $\begin{array}{l}60 \\
70^{\star}\end{array}$ & -+- & I mth & Alive \\
\hline 26 & 69 & $\mathbf{M}$ & $\begin{array}{l}\text { AWMI, } \\
\text { RBBB-LPH }\end{array}$ & & & 80 & 80 & + & $9 \mathrm{hr}$ & Died, VF \\
\hline 27 & $5 I$ & $\mathbf{M}$ & $\begin{array}{l}\text { AWMI, } \\
\text { RBBB-LAH }\end{array}$ & CHB day 2 & & I 10 & 55 & -+ & II dy & Died, VF \\
\hline 28 & 83 & $\mathbf{M}$ & AWMI & RBBB-LAH day I & $\begin{array}{r}5 / 6 \\
14 / 6\end{array}$ & $\begin{array}{l}90 \\
85\end{array}$ & $\begin{array}{l}50 \\
55\end{array}$ & -+- & 3 wk & Alive \\
\hline
\end{tabular}

+ Necropsy $\star$ IBBBB not present + No pacemaker at time of death.

AWMI, anterior wall myocardial infarction; RBBB, right bundle-branch block ( + present, - absent); LAH, left anterior hemiblock; IWMI, inferior wall myocardial infarction; OIWMI, old inferior wall myocardial infarction; CHB, complete heart block; VF, ventricular fibrillation; CHF, congestive heart failure; LPH, left posterior hemiblock; AF, atrial fibrillation; CVA, cerebrovascular accident; LBBB, left bundle block (ILBBB, incomplete): AF, artial fibrillation: $\mathrm{I}^{\circ} \mathrm{AV}$, first degree atroventricular block. 
who died of congestive heart failure, had electrocardiographic evidence of both anterior and inferior wall myocardial infarction in addition to right bundle-branch block with periods of both left anterior and left posterior hemiblock: recent occlusion of both the right coronary artery and left anterior descending coronary artery was found. Case 20 had electrocardiographic evidence of anterior wall myocardial infarction, right bundlebranch block with left anterior hemiblock, and transient complete heart block. Examination revealed recent occlusion of the proximal left anterior descending coronary artery and extensive necrosis involving the anterior wall, septum, and apex of the right ventricle.

Twenty-three patients had an abnormal HV interval ( $55 \mathrm{~ms}$ or greater). Fifteen of these patients died $(65 \%)$ while only I $(20 \%)$ died in the group of 5 with a normal HV interval. All 9 patients with right bundle-branch block and left posterior hemiblock had an abnormal HV interval and 7 died.

Examination of serial electrocardiograms showed disappearance of incomplete bilateral bundle- branch block in 7 of the 12 survivors and in only 2 of the 16 who did not survive.

Sequential His bundle recordings were done in 6 of the 8 survivors with an initially abnormal HV interval. Four showed a 10 to $15 \mathrm{~ms}$ decrease in HV interval while 2 showed no significant change. Sequential studies were done in 2 of the 4 survivors with an initially normal $\mathrm{HV}$ interval and neither showed a significant change. Sequential studies were done in 2 of the 15 who had an abnormal HV interval and did not survive. One showed no significant change and the other a $10 \mathrm{~ms}$ increase. The I2 surviving patients have been followed for a period ranging from $I$ to 22 months.

Fig. I (Case 15) summarizes the significant electrocardiographic findings of a 55-year-old man. The tracing of II October 1972 demonstrates the absence of intraventricular conduction defects before myocardial infarction. On 12 April 1973 during his first week in hospital the abnormalities of acute anterior wall myocardial infarction, right bundle-branch block and left anterior hemiblock, are noted.

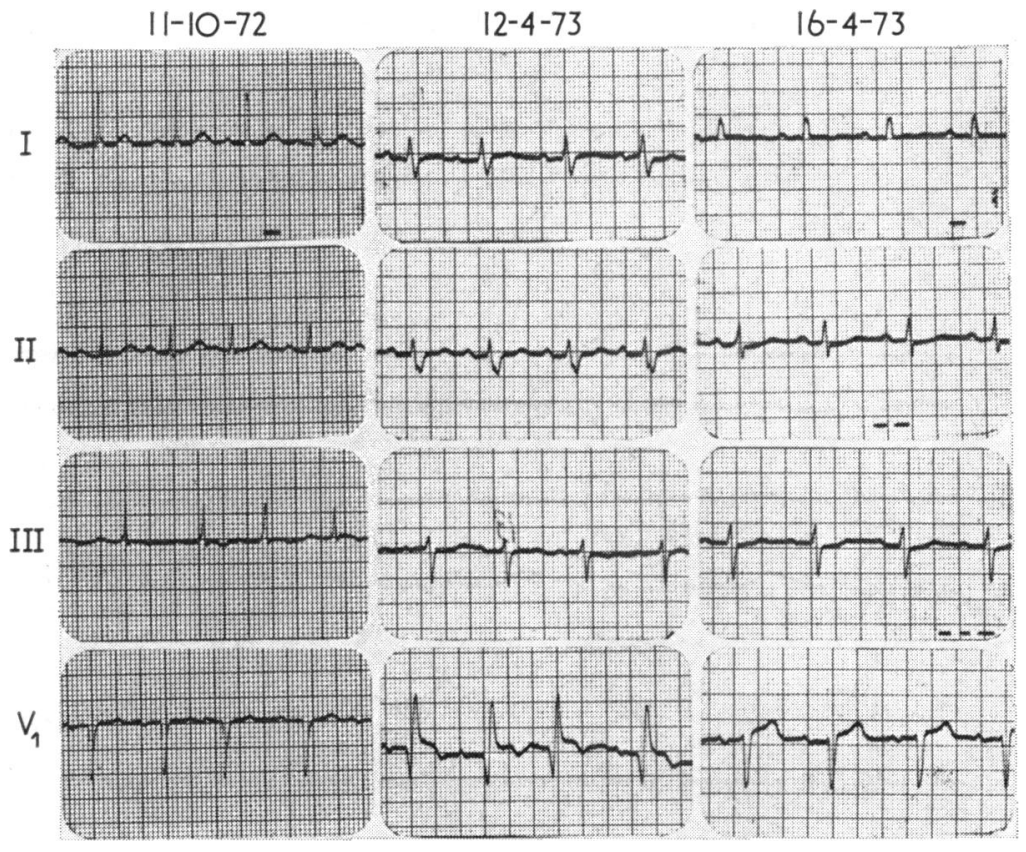

FIG. I Summary of significant electrocardiographic changes in Case 15. II October 1972 shows absence of intraventricular conduction defect before myocardial infarction. On 12 April 1973 there is evidence of acute anterior wall myocardial infarction in addition to right bundlebranch block and left anterior hemiblock. On 16 April 1973 the right bundle-branch block has disappeared and the frontal plane $Q R S$ axis has shifted towards normal. 


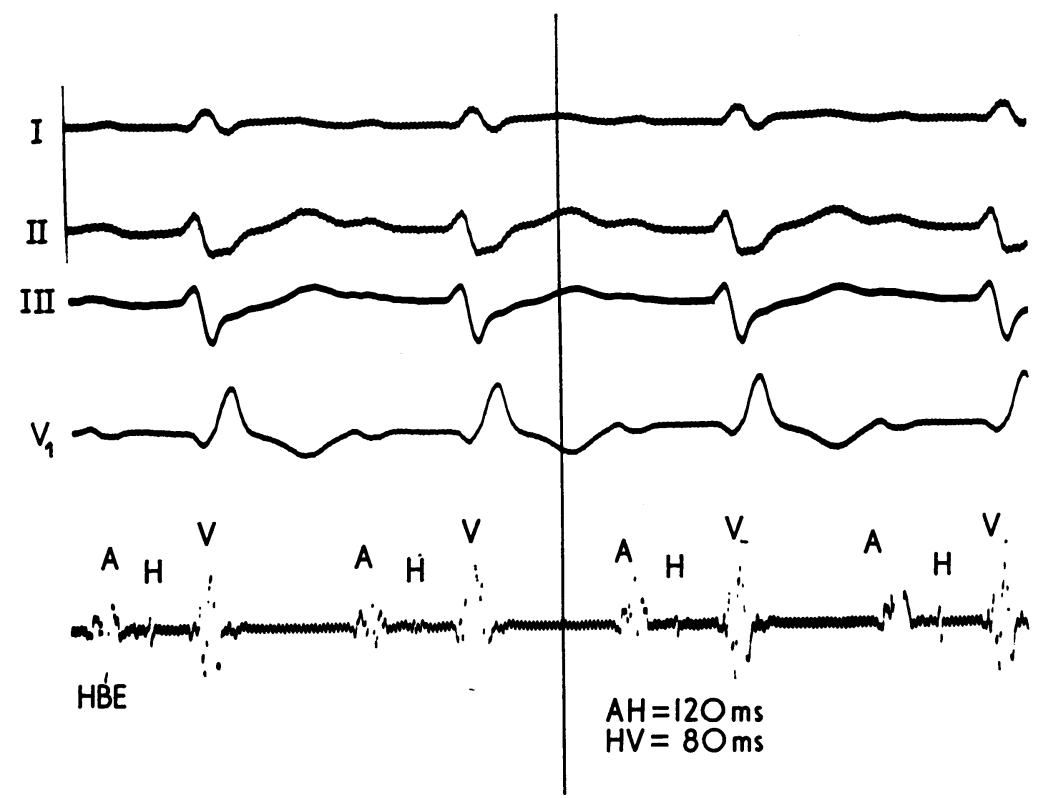

FIG. 2 His bundle electrogram (HBE) bilateral in Case 15 recorded during pacemaker insertion. Incomplete bilateral bundle-branch block is present and the HV interval is prolonged. $A=$ atrial depolarization; $H=H i$ is bundle potential; $V=$ ventricular depolarization. Time lines are one second.

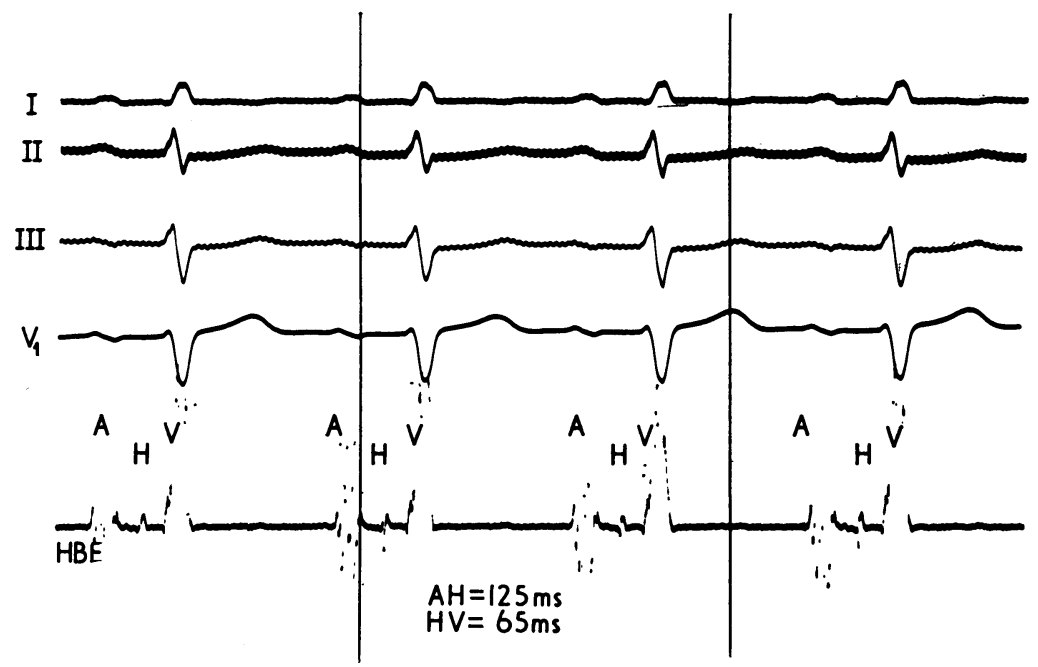

FIG. 3 His bundle electrogram in Case 1521 days later showing a $15 \mathrm{~ms}$ decrease in the HV interval. Incomplete bundle-branch block is no longer present. Abbreviations and time lines as in Fig. 2. 
On 16 April 1973 the right bundle-branch block has disappeared and the frontal plane QRS axis has shifted towards normal. Fig. 2 shows this patient's His bundle electrocardiogram at the time of temporary pacemaker insertion and demonstrates moderate prolongation of the HV interval. Fig. 3 is the His bundle electrogram recorded at 21 days showing a $15 \mathrm{~ms}$ decrease in $\mathrm{HV}$ interval.

\section{Discussion}

The mortality associated with incomplete bilateral bundle-branch block complicating acute myocardial infarction remains high. The reported hospital mortality varies from 30 per cent (Atkins et al., I973) to 7 I per cent (Gould et al., 1972), with several other studies within this range (Godman et al., 1970; Roos and Dunning, 1970; DePasquale and Bruno, 1973). Our hospital mortality of 43 per cent falls roughly in the middle of those reported. The reasons for this variability include the small size of the patient groups in addition to the varying criteria for inclusions in the different studies.

A feature found in most studies was that most deaths were caused by pump failure (Atkins et al., 1973) or ventricular fibrillation (Gould et al., 1972) and that the mortality remained high in spite of temporary pacemaker insertion. The causes of death during the hospital period in our group were ventricular fibrillation in 8 , cardiogenic shock in 2 , congestive heart failure in $I$, and respiratory arrest in I. In all but I patient with ventricular fibrillation in this group, a temporary demand pacemaker was in place. In the I exception, the pacemaker had been removed at $\mathbf{I} 4$ days because of fever. Ventricular fibrillation was documented during resuscitation but since this patient was not on constant monitoring, a period of complete heart block preceding ventricular fibrillation could have occurred.

Follow-up studies indicate that these patients have a poor prognosis (Scanlon et al., 1970). Of our I6 patients who survived the initial 21 days in hospital, $4(25 \%)$ died between 6 weeks and 4 months. Causes of these late deaths included progressive congestive heart failure (Case II) and cerebral vascular accident (Case 17). There were 2 late deaths that occurred suddenly; one (Case 3 ) is presumed to have been caused by ventricular fibrillation in a patient with a functioning permanent pacemaker while the other (Case 9) was of unknown mechanism.

The question arises as to whether these isolated instances of sudden death under questionable circumstances warrant recommendation of permanent pacemaker implantation. Atkins et al. (1973) have made this suggestion for the specific subgroup of patients who have documented transient complete heart block, and he has shown an increased survival when this is done. We agree with this recommendation but have had little opportunity to implement it, since 75 per cent of our patients with complete heart block died within the first 21 days in hospital. Waugh et al. (1973) recommend permanent pacemakers for certain high risk groups such as those with adjacent fascicular block and a prolonged PR interval.

Our 14 per cent incidence of complete heart block is lower than that reported by others. It is possible that transient complete heart block occurred in our patients after monitoring was discontinued and was not noted clinically because of the temporary demand pacemaker. Since this possibility exists in our group and probably in others, a decision concerning the advisability of a permanent pacemaker must be made in all patients who survive the initial period in hospital.

In an attempt to answer this question, we have studied various features of those who survived as opposed to those who did not.

Of the 12 survivors, 7 had transient incomplete bilateral bundle-branch block, while this transient nature of the block was observed in only 2 of the 16 who expired. This improved prognosis when the intraventricular conduction defect is transient has been noted by others. Norris (1969) describes 6 patients with heart block complicating anterior wall myocardial infarction and noted persistence of bundle-branch block after return to normal atrioventricular conduction in the 4 patients who died, but gradual return to normal intraventricular conduction in the 2 survivors. Lassers (1969) reported 4 deaths in 5 patients who left the hospital with right bundle-branch block after acute myocardial infarction. In the I surviving patient, the right bundlebranch block disappeared after hospital discharge. Bauer (1964) has also described a better prognosis in patients with transient bundle-branch block.

In a previous report (Lichstein et al., 1973) concerning a smaller group of similar patients, we noted better prognosis in patients with a normal $\mathrm{HV}$ interval (less than $55 \mathrm{~ms}$ ). Study of this larger group of patients confirms the earlier finding. Though the group with normal $\mathrm{HV}$ interval was small, there was only I death in 5 patients $(20 \%)$. There were 15 deaths $(65 \%)$ in the 23 patients with an abnormal HV interval. This increased mortality was also noted by Denes et al. (1975) in a group of patients with a prolonged $\mathrm{HV}$ interval and chronic bifascicular block. Since most of these deaths were caused by pump failure and ventricular fibrillation, the poor prognosis is probably caused by extensive necrosis involving all fascicles of the conducting 
system. In addition to the $\mathrm{HV}$ interval measured during pacemaker insertion, a second recording was obtained in Io patients. Eight patients with an abnormal $\mathrm{HV}$ interval survived, and $6 \mathrm{had}$ sequential His bundle recordings: 4 of these sequential recordings demonstrated a 10 to $15 \mathrm{~ms}$ decrease in HV interval, while there was no significant change in 2. Since a prolonged HV interval is thought to represent trifascicular disease, it is usually found in the presence of a wide QRS. This was not seen in Cases 15, 2I, and 25 who had a normal QRS duration with a prolonged $\mathrm{HV}$ interval, which may have represented block within the His bundle, as has been noted in myocardial infarction experimentally and clinically (El-Sherif et al., 1974). The pathological lesion associated with anterior wall myocardial infarction and heart block is massive septal infarction with necrosis involving both bundles (Rosen et al., 1970). Haemorrhage into and around the bundle-branches has also been noted (Sutton and Davies, I968). In our patients with transient bundle-branch block and a decreasing HV interval, oedema and inflammatory cell infiltration similar to that seen at the atrioventricular node may have been present.

We conclude that long-term survival is possible after incomplete bilateral bundle-branch block complicating acute myocardial infarction. The features of this group of survivors include an initially normal HV interval, incomplete bilateral bundlebranch block which is only transient, and a decreasing HV interval if it were initially abnormal.

\section{References}

Atkins, J. M., Leshin, S. J., Blomqvist, G., and Mullins, C. B. (1973). Ventricular conduction blocks and sudden death in acute myocardial infarction. New England fournal of Medicine, 288, $28 \mathrm{I}$.

Bauer, G. E. (1964). Transient bundle-branch block. Circulation, 29, 730 .

Benchimol, A., Desser, K. B., and Massey, B. J. (1972). Coexisting left anterior hemiblock and inferior wall myocardial infarction. Vectorcardiographic features. American fournal of Cardiology, 29, 7.

Denes, P., Dhingra, R. C., Wu, D., Chuquima, R., Amat-YLeon, F., Wyndham, C., and Rosen, K. M. (1975). H-V interval in patients with bifascicular block (right bundle branch block and left anterior hemiblock). American fournal of Cardiology, 35, 23.

DePasquale, N. P., and Bruno, M. S. (1973). Natural history of combined right bundle branch block and left anterior hemiblock (bilateral bundle branch block). American Fournal of Medicine, 54, 297.

El-Sherif, N., Scherlag, B. J., Lazzara, R., Hope, R., Williams, D. O., and Samet, P. (1974). The pathophysiology of tachycardia-dependent paroxysmal atrioventricular block after acute myocardial ischemia: experimental and clinical observations. Circulation, 50, 515.
Fenig, S., and Lichstein, E. (1972). Incomplete bilateral bundle branch block and A-V block complicating acute anterior wall myocardial infarction. American Heart fournal, 84, 38.

Godman, M. J., Lassers, B. W., and Julian, D. G. (I970). Complete bundle-branch block complicating acute myocardial infarction. New England fournal of Medicine, 282, 237.

Gould, L., Venkataraman, K., Mohammed, N., and Gomprecht, R. F. (1972). Prognosis of right bundle-branch block in acute myocardial infarction. Fournal of the American Medical Association, 219, 502.

Lassers, B. W. (1969). First-year follow-up after recovery from acute myocardial infarction with complete heartblock. Lancet, I, II72.

Lassers, B. W., and Julian, D. G. (1968). Artificial pacing in management of complete heart block complicating acute myocardial infarction. British Medical fournal, 2, I42.

Lichstein, E., Gupta, P. K., Chadda, K. D., Liu, H. M., and Sayeed, M. (1973). Findings of prognostic value in patients with incomplete bilateral bundle branch block complicating acute myocardial infarction. American fournal of Cardiology, 32, 913.

New York Heart Association, Criteria Committee (1964). Diseases of the Heart and Blood Vessels, 2nd ed., p. 423. Little, Brown, Boston.

Norris, R. M. (1969). Heart block in posterior and anterior myocardial infarction. British Heart fournal, 31, 352.

Roos, J. C., and Dunning, A. J. (1970). Right bundle-branch block and left axis deviation in acute myocardial infarction. British Heart fournal, 32, 847.

Rosen, K. M., Loeb, H. S., Chuqimia, R., Sinno, M. Z., Rahimtoola, S. H., and Gunnar, R. M. (1970). Site of heart block in acute myocardial infarction. Circulation, 42, 925 .

Rosenbaum, M. B. (1970). The hemiblocks; diagnostic criteria and clinical significance. Modern Concepts of Cardiovascular Disease, 39, I41.

Scanlon, P. J., Pryor, R., and Blount, G. S. (1970). Right bundle-branch block associated with left superior or inferior intra-ventricular block. Associated with acute myocardial infarction. Circulation, 42, I1 35.

Scheinman, M., and Brenman, B. (1972). Clinical and anatomic implications of intraventricular conduction blocks in acute myocardial infarction. Circulation, 46, 753.

Scherlag, B. J., Lau, S. H., Helfant, R. H., Berkowitz, W. D., Stein, E., and Damato, A. N. (1969). Catheter technique for recording His bundle activity in man. Circulation, 39, 13.

Sutton, R., and Davies, M. (1968). The conduction system in acute myocardial infarction complicated by heart block. Circulation, 38, 987.

Varriale, P., and Kennedy, R. J. (1972). Right bundle branch block and left posterior fascicular block; vectorcardiographic and clinical features. American fournal of Cardiology, 29, 459.

Waugh, R. A., Wagner, G. S., Haney, T. L., Rosati, R. A., and Morris, J. J. (1973). Immediate and remote prognostic significance of fascicular block during acute myocradial infarction. Circulation, 47, 765 .

Requests for reprints to Dr. Edgar Lichstein, Division of Cardiology, Mount Sinai Hospital Services, City Hospital Center at Elmhurst, 79-Or Broadway, Elmhurst, New York I 1373, U.S.A. 